\title{
What Do Near-Death Experiencers and Jesus Have in Common? The Near-Death Experience and Spong's New Christianity
}

\author{
John C. Gibbs, Ph.D. \\ The Ohio State University
}

\begin{abstract}
Persons who have had near-death experiences (NDEs) typically become less self-centered or more spiritual, evidencing an expansive love much like that attributed to Jesus Christ. According to traditional Christianity, these common qualities fail to capture a profound discontinuity: whereas NDErs are human, Jesus was divine. John Shelby Spong has taken issue with this discontinuity view, arguing for a more "authentic" view of Jesus, a more spiritual understanding of humanity, and a new, evolving Christianity. This article relates near-death phenomena to Spong's argument. Various aspects of near-death research findings converge in pointing toward a deeper human spiritual reality of love and connection. In other words, humans, despite varying degrees of self-centeredness and distortion, may nonetheless in some ultimate sense all be integral to the light of divine love. This implication of near-death research is congruent with Spong's continuity view that humanity and divinity are not discontinuous but instead blend or flow together. Neardeath research and Spong's envisioned new Christianity share in principle the ideal of progress through challenge and open dialogue.
\end{abstract}

KEY WORDS: near-death experience; Christianity; nonlocality; panentheism; Spong.

John Gibbs, Ph.D., is Professor of Developmental Psychology at the Ohio State University, Columbus, $\mathrm{OH}$. For their encouragement and/or constructive criticism in response to a preliminary version of this article, he thanks Bill Bendschneider, James Day, Steve Fanning, Jon Gibbs, Stephanie Gibbs, Valerie Gibbs, Phil Grandinetti, Kurt Keljo, Stephanie Kamath, Sophia Kim, Clark Power, Lea Queener, Mike Sabom, John Snarey, Jack Spong, and Brenda Wilbee. Reprint requests should be addressed to Dr. Gibbs at Psychology Department, the Ohio State University, 137 Townshend Hall, 1885 Neil Avenue, Columbus, $\mathrm{OH} 43210$; e-mail: gibbs.1@osu.edu. 
Persons who have had so-called near-death experiences (NDEs) typically become less self-centered or more spiritual. NDErs commonly attribute to the experience not only their subsequent declines in concern with material self-aggrandizement or social status, but also their subsequent gains in love for others in terms of acceptance, understanding, and caring. More than nonNDE survivors, they report an inner sense of divine presence as well as insight into the problems of others. They also report having a profound appreciation of the present moment and the "ordinary" things of life. Their gains in love extend to strangers. NDErs may shift their occupation to one of the helping professions, volunteer in a social or community service, or join humanitarian causes. Interestingly, the "deeper" the experience, the greater its spiritual impact (Bonenfant, 2004; Greyson, 1992-1993, 2000; Ring, 1980, 1984; Sabom, 1982, 1998; Schwaninger, Eisenberg, Schechtman, and Weiss, 2002; van Lommel, van Wees, Meyers, and Elfferich, 2001).

In religious terms, one might say that near-death experiencers by virtue of their experience tend to become more Christ-like. Jesus, too, according to the New Testament, lived in the moment and had little concern with self-aggrandizing plans, material wealth, or social status. He, too, profoundly loved, understood, and cared for others, be they men, women, or children. Jesus' love was expansive, reaching to tax collectors, prostitutes, adulterers, and "outsiders" like Samaritans and gentiles.

According to traditional Christianity, of course, emphasizing the qualities that may be common to NDErs and Jesus misses a profound discontinuity: whereas NDErs are human, Jesus was and is divine. Whereas humans are sinners in a fallen world, Jesus was without sin, the perfect lamb sacrificed on the cross in atonement for the sins of humanity. Whereas humans are creatures of the creation, Jesus was the only Son of God, the Creator of all things. Unlike humans who may have spiritual experiences such as NDEs, Jesus was unique on earth as a spiritual being, as God. While on earth, Jesus the Son of God endured a human experience of suffering and agonizing death for our sakes. Again, we are human, Jesus was and is divine; except for that unique event of God among humans, "human" and "divine" are discontinuous entities.

In a number of theological works building from those of Rudolf Bultmann, Meister Eckhardt, and Paul Tillich, the Episcopal bishop John Shelby Spong has taken issue with this discontinuity view of Jesus espoused by traditional Christianity. Instead, Spong has argued 
the need for a more "authentic" view of Jesus, a more spiritual understanding of humanity, and a new Christianity. In Spong's view, there is no basic discontinuity between NDErs and Jesus, between persons and God. "These two words - human and divine - do not point to separate entities; rather they are like two poles of a continuum that ... blend into and invade each other" (Spong, 2001, p. 83). Although Jesus was so suffused with spirituality that in seeing Jesus we can see God, in the final analysis (according to Spong), Jesus Christ differed from us in degree rather than in kind. Spong's view has sparked controversy (Moore, 1998).

What does it mean to say that NDEs can stimulate persons to become "more" spiritual, or that Jesus in Spong's view was "more" profoundly spiritual? Are there individual differences in the extent to which a person is spiritual or becomes suffused in earthly life with spirituality? Is there a deeper spiritual reality to human existence? To address such questions, we must ask: What is the NDE? Can it tell us anything about reality? about human life or spirituality or divinity? What are its implications with regard to Spong's view of Jesus, humanity, and Christianity?

In this article, I will ponder these questions, devoting extensive initial attention to NDEs and their ontological and spiritual significance. I will then consider Spong's work. The implications of findings in the near-death research literature seem congruent with Spong's continuity view of Jesus, spiritual view of humanity, and call for a new Christianity.

\section{The Near-Death Experience}

Bruce Greyson has defined the NDE as a set of "profound psychological events with transcendental and mystical elements, typically occurring to individuals close to death or in situations of intense physical or emotional danger" (2000, p. 316). Among various proposed typologies, the most elegant may be Michael Sabom's tripartite classification of near-death experiences as: (a) autoscopic (literally, self-visualizing; most broadly, perceiving from an elevated vantage point one's physical body and its surrounding earthly situation), (b) transcendental (moving through a dark region or void to an otherworldly realm of loving light; encountering and mentally communicating in that realm with an indescribably bright light, deceased loved ones, or spiritual figures; reviewing events of one's 
earthly life; and reaching some border, limit, or barrier), and (c) combined, such that "the transcendental portion of the experience follow[s] the autoscopic portion in a continuous, unbroken sequence" (1982, p. 52). I will use Sabom's typology in pondering the ontological and spiritual significance of the NDE.

\section{Ontological Significance}

A key issue pertaining to the autoscopic and especially to the transcendental or combined NDE is the question of its implications for our understanding of the reality of human existence. In Susan Blackmore's (1993) terms, the issue is whether the NDE is "a glimpse into ... a non-material world" (pp. 3-4), "penetrating into [an] underlying reality" of human existence (p. 161); or a composite of "products of the dying brain: hallucinations, imaginings, and mental constructions that will ultimately stop when the brain's activity stops" (p. 4). A full treatment of this issue is not feasible within the space of this article, but has been extensively reviewed elsewhere (Gibbs, 1985, 1997, 1999, 2003; Greyson, 2000; Potts, 2002; Sabom, 1982, 1998). "Dying brain" explanations of the phenomenon have included references to endorphins, cerebral hypoxia, hypercapnia, hallucinogenic agents such as ketamine and phencyclidine, serotonin pathways, limbic system activation, and temporal lobe anoxic seizures (Blanke. Ortigue, Landis, and Seeck, 2002; Parnia and Fenwick, 2002; Vaitl, Birbaumer, Gruzelier, Jamieson, Kotchoubey, Kübler, Lehmann, Miltner, Ott, Pütz, Sammer, Strauch, Strehl, Wackermann, and Weiss, 2005).

Could it be that the NDE (especially the transcendental and combined NDE) does afford some sort of access into a deeper reality of human existence? If NDErs have in fact glimpsed a deeper reality, then what relevance might that have for questions of spirituality and Christianity? I will draw upon the research literature to ponder five ontologically relevant questions: (1) Does the context of the near-death experience influence and even determine its content? (2) Do neardeath experiencers interpret the experience as real? (3) Are verifiable aspects of the near-death experience in fact accurate or veridical? (4) Is the depth of the experience associated with proximity to physical death? And (5) does the typical near-death experience take place while the person is actually near death? 


\section{Does the Context Influence and Even Determine the} Content of the Near-Death Experience?

Near-death experiences have occurred across a broad range of life contexts. A context is a relevant and influential background, condition, or set of surrounding circumstances. The immediate context of the NDE is a life-threatening situation, such as major surgery, a serious accident, a grave illness, a suicide attempt, or intense danger. More broadly, however, the context includes everything brought to the experience by the experiencers themselves: their age, gender, educational level, ethnic status, marital status, occupation, culture, religious background, mental health, knowledge of near-death experiences, historical time period, and so on. We may even include as context the individual's cultural and personal frameworks or schemas: their attitudes, beliefs, needs, desires, hopes, and expectations at the time of the life-threatening situation.

Context may not influence the likelihood of having an NDE, as NDErs do not differ in most respects from nonNDEr survivors (Greyson, 2000; Schwaninger, Eisenberg, Schechtman, and Weiss, 2002). However, context may nonetheless make a difference in the particular description of the experience. Allan Kellehear (1996) found that descriptions such as movement through a tunnel or cylinder such as a pipe (a truck driver reported by Mally Cox-Chapman [1995, p. 17] experienced being "shot through a tailpipe toward a brilliant light") are generally provincial to Western near-death experiences. Indian, Chinese, Melanesian, and other rural or village cultures described experiences such as walking through dark fields or emerging through the calyx (throat) of a lotus flower or traveling through subterranean caves. Although Western and nonWestern respondents brought different contexts to their experiences, Kellehear inferred that respondents in both types of culture were "attempting to describe some kind of movement through darkness" and into a transcendent or otherworldly realm (1996, p. 37). Especially in Western cultures, the transcendent realm not only follows movement through darkness but entails the presence of a being or figures of light.

Although description of the NDE is influenced by context, the phenomenon does not appear to be entirely reducible to contextual factors such as culture, subjective expectation or desire, and situational activities. Autoscopic, transcendental, and combined NDEs have been evident even among persons who had not known of such experiences. NDEs have been reported even by young children, despite 
their limited and idiosyncratic cultural or religious expectations. It is intriguing that child survivors whose parents were present and highly salient nonetheless generally report having encountered in the light deceased loved ones (Greyson, 2000).

Furthermore, NDErs express difficulty in finding adequate words to describe the experience, details of which they may find baffling. Although not strong evidence (Blackmore, 1993), odd or surprising events - especially those that continue to baffle - do suggest an ontological status beyond subjective imagination. An experiencer named Elinor remembered that her

father loved having friends and family around. The fact that it still seems odd to Elinor that her father would have turned down her company ["All he said to me was, 'Sweetheart, don't come"] gives credence to the possibility that her vision is not simply a construct of her imagination. (Cox-Chapman, 1995, p. 134)

A classic criterion of a genuinely transcendental or mystical experience is "ineffability," that is, that "no adequate report of its contents can be given in words" (James, 1902/1958, pp. 292-293). The experiencer can only approach the experience in terms of the preexisting schemas (or frameworks for meaning) of his or her given life, times, and culture. It is perhaps not coincidental that ineffability (as implied in expressions of communicative frustration, surprise, or bafflement) was totally absent from an NDE account that was subsequently identified by Kenneth Ring and Madelaine Lawrence (1993) to have been a fabricated composite description of an NDE (Gibbs, 1997).

\section{Do NDErs Interpret the Experience as Real?}

NDErs usually report enhanced conscious awareness and perceptual clarity as well as a sense that their experience was real. Experiencers who remember their dreams or have had hallucinations typically distinguish their NDE as neither dream nor hallucination (Ring, 1980; Sabom, 1982). One respondent said, "It was too real. Dreams are always fictitious. This was me, happening at that time and there was no doubt that it was reality" (Ring, 1980, p. 82). Regarding the distinguishability of hallucinations as only pseudo-real by comparison, Greyson (2001) recounted an astonishing incident in which a psychiatric patient of his began a suicide attempt by overdosing on a medication, changed his mind and dialed the phone for 
help, started hallucinating little people in his kitchen and crawling around his legs, and then had an autoscopic NDE:

He drew back out of his body and from a position of about 10 feet behind his body he looked at himself holding the phone. He saw his body looking around. ... He couldn't see any little people; he was mentally clear. But he remembered being inside the body and he knew that his body was hallucinating. He told me: " $I$ wasn't hallucinating but my body was!"

Some NDErs even suggest that their experience was more real than is the physical world. One respondent stated: "the reality in which we are currently existing is in fact a lesser reality than the reality of the light" (Farr, 1993, p. 51). One of Sabom's patients described the experience as "realer than here" $(1982$, p. 16). Nonetheless, the "lesser" reality of earthly existence is evidently of some ontological status and importance in its own right. An additional common impression of NDErs is that their return has some reason or purpose, typically involving learning, spiritual growth, and love. As noted, among NDE aftereffects are a heightened love and desire to help or care for others, including in some cases broad humanitarian concerns. Although interpreting an experience as real does not make it so (Blackmore, 1993), such claims do invite investigation as to whether they could be correct.

\section{Are Verifiable Aspects of the NDE in Fact Accurate?}

A crucial empirical strategy for assessing whether NDEs are purely subjective imaginal projections or something more than that is to investigate the empirical accuracy or veridicality of their confirmable features. Most amenable to such investigations are perceptions reported in the autoscopic NDE (or the autoscopic portion of the combined NDE).

Rather astonishing evidence for accuracy is provided by the case of Pam Reynolds, whose combined NDE occurred during six hours of major surgery in 1991 (Sabom, 1998). Reynolds was extensively interviewed at least two years after her near-death event. Had she been interviewed sooner after the event, however, her account probably would have been highly similar. Pim van Lommel and colleagues (van Lommel, van Wees, Meyers, and Elfferich, 2001) found almost no longitudinal difference in survivors' near-death recollections at three points in time (a few days, two years, and eight years later). Greyson (personal communication, June 3, 2005) found similar results after a 20-year interval. 
Reynolds' surgery entailed a new and daring procedure called hypothermic cardiac arrest. Its aim was to remove a brain aneurysm so large as to be inoperable by traditional procedures. Excision of the giant aneurysm required its collapse ("like a deflated balloon," Sabom, 1998, p. 45) as the blood in the arteries of the brain, and indeed the entire body, was drained "like oil from a car" (p. 43). During the surgery, Reynolds' eyes were taped shut, ear canals occluded, and body deeply anesthetized. Her brain waves ceased and heart stopped beating as the blood was drained from her body. Nonetheless, she reported numerous idiosyncratic visual and auditory details, such as the pitch and shape of the cranial saw, her partially shaven head, and surgeons' comments - all of which were found to be accurate.

Reynolds' accuracy corroborated an earlier finding by Sabom (1982) of veridicality in autoscopic NDEs. Before his first study, Sabom had been convinced that "the near-death experience, if properly studied, could be reduced to a simple scientific explanation" (Sabom, 1998, p. 175). At the onset of his first study, Sabom

had been eagerly awaiting the moment when a patient would claim that to have "seen" what had taken place during his resuscitation. Upon such an encounter, I intended to probe meticulously for details which would not ordinarily be known to nonmedical personnel. In essence, I would pit both my experience as a trained cardiologist and the description of the resuscitation in the medical chart against the professed visual recollections of a lay individual. ... [In so doing,] I was convinced [that] obvious inconsistencies would appear which would reduce these "visual" observations to no more than "educated guesses." (1982, p. 83)

Sabom interviewed 32 such patients. All of their accounts of hospital cardiopulmonary resuscitation (CPR) procedures were accurate, including six particularly detailed recollections. The recollected details in each case were "fairly specific for the actual resuscitation being described and ... not interchangeable with the clinical circumstances of other near-death crisis events" (Sabom, 1982, p. 114). One participant did make apparent errors in his describing the operation of a defibrillating meter - until Sabom, to his astonishment, discovered that that description matched an older model that was still in common use in 1973, at the time of the patient's cardiac arrest.

To establish a baseline rate of accuracy attributable to educated guesses, Sabom also interviewed a control group of 25 patients with comparable cardiac-related background and hospital experience but who had not reported an NDE. These patients were asked what they 
would expect to see if they were to watch a hospital CPR procedure; 23 provided such a description. The baseline rate of accuracy was extremely low; only three of these 23 participants avoided making a "major error" (p. 85) in their imaginative descriptions. The accuracy rate of the group reporting specific autoscopic recollections, then, was overwhelming and not attributable to projections from common knowledge.

Although verifiability refers mainly to the earthly perceptions of the autoscopic NDE, it can also apply in an indirect way to transcendental near-death perceptions of deceased loved ones. In the transcendental portion of Reynolds' NDE, she "recognized a lot of people" (all deceased) among the "figures in the light" ("they were light") that "began to form shapes" (Sabom, 1998, p. 44). In some cases, experiencers describe encounters with unfamiliar figures whose identities are only subsequently recognized. Child survivors, for example,

purportedly describe meeting persons, whom they did not know, in sufficient detail to allow their parents to recognize those persons as deceased relatives, or the child may later identify the person from the NDE in a family portrait [or photograph] he or she had never seen before. (Greyson, 2000, p. 341)

An adult whose NDE occurred in childhood reported that while in the light, he became aware that

there were some presences there. There were some ladies. ... I didn't know them at the time. ... They were so loving and so wonderful and I just didn't want to come back. ... I didn't see any pictures of them until I was an adult, but then I said, "Oh, yeah." ... They were my great-grandmothers who had died years before I was born. (Wilson, 1995)

Such corroboration of encounters that could scarcely be projections of the familiar also sometimes occurs in connection with the related phenomenon variously termed "deathbed vision" (Osis and Haraldsson, 1977), "nearing-death awareness" (Callanan and Kelley, 1992), or "approaching-death experience" (Fenwick, 2005). Most pertinent are those cases in which the experiencer sees recently deceased loved ones whose deaths were unknown to them. Maggie Callanan and Patricia Kelley recounted the case of a dying 93-year-old Chinese-American woman, $\mathrm{Su}$, whose visions began to include not only her late husband but also her sister:

"Why is my sister with my husband?" she asked. "They are both calling me to come." 
"Is your sister dead?" I [Callanan] asked.

"No, she still lives in China," she said. "I have not seen her for many years."

When I related this conversation to the daughter [Lily], she was astonished and tearful.

"My aunt died two days ago in China," Lily said. "We decided not to tell Mother - her sister had the same kind of cancer. It was a very painful death; she lived in a remote village where good medical care wasn't available. We didn't want to upset or frighten Mother, since she is so sick herself." ...

When Lily tearfully told her mother about her sister's illness and death, Su said, with a knowing smile, "Now I understand." Her puzzle solved, she died three weeks later, at peace and with a sense of anticipation. (Callanan and Kelly, 1992, pp. 93-94)

\section{Is the Depth of the Experience Associated with Proximity to Physical Death?}

Although measures of NDE "depth" are subject to questions of validity (Greyson, 2000, pp. 342-345), it is worth noting that Reynolds' depth score on Greyson's (1983) Near-Death Experience Scale was 27 of a possible maximum score of 32 . This score far exceeded the mean of 13.3 in Sabom's (1998) sample of 47 experiencers and in fact was the highest score of anyone in the study. This concurrence of a clinically extreme near-death condition with a deep NDE is consistent with the research literature. Although aspects of the NDE can occur in deep meditation or "situations of intense physical or emotional danger," typically it occurs "to individuals [actually] close to death" (Greyson, 2000, pp. 315-316). Ring (1980) and Sabom (1982) both found that ratings of NDE depth correlated with ratings of closeness to physical death. Van Lommel and colleagues (van Lommel, van Wees, Meyers, and Elfferich, 2001) found in their prospective study that those survivors who died within 30 days of their initial interview were more likely to have had an NDE and, in particular, a "deep" one.

Why would the NDE be more likely to occur the closer one is to physical death? Perhaps the onset of the NDE entails what Sabom referred to as

a mind-brain split. If the human brain is actually composed of two fundamental elements - the "mind" and the "brain" - then could the near-death crisis event somehow trigger a transient splitting of the mind from the brain in many individuals? $(1982$, p. 183)

Similarly, Jenny Wade (1996) attributed human consciousness to brain-based and transcendent sources and speculated that the former 
typically displaces the latter during earthly life, except during certain circumstances of compromised brain function as in the NDE.

If the mind (or transcendent aspect of consciousness) separates from the brain (or brain-based consciousness) in the NDE, then perhaps there are individual differences in what is required for the separation to occur. The range of individual differences may be considerable. For some individuals, the mere exertion of will or intimation of intense danger may suffice to trigger a split of "mind" or "self" from the physical brain. At the other end of the continuum, the threshold for mind-brain split may be so high for some that the split may not occur until actual physical death.

\section{Does the Typical NDE Take Place While the Person is Actually Near Death?}

If near-death perceptions are to some remarkable degree veridical or accurate, experienced as real, and even highly conscious and clear, then how could they be taking place at a time of severe mental and bodily compromise, of proximity to death? One answer attributes the experience to special effects of a dying or severely compromised brain. Blackmore (1993) and Olaf Blanke and his colleagues (Blanke, Ortigue, Landis, and Seeck, 2002) argued that the disinhibited seizure activity of a dying brain could generate seemingly "real" hallucinations. Sam Parnia and Peter Fenwick countered that the "disorganised and compromised cerebral function" evident during near-death states is unlikely to produce the "lucid, well structured thought processes" characteristic of the NDE (2002, p. 8), echoing the earlier findings of Justine Owens, Emily Cook, and Ian Stevenson (1990). Seizures can be ruled out as an explanation in Reynolds' case, where electroencephalographic (EEG) records documented the absence of such activity (M. Sabom, personal communication, Sept. 20, 2002).

"Compromised" is an understatement as a description of Reynolds' brain function. By the time she was experiencing the transcendental aspects of her experience, the EEG record was showing that her brain was not only functionally compromised but indeed "dead" by all three of the standard clinical criteria: (a) a "flat" EEG, indicating nonfunction of the cerebral cortex; (b) absence of auditory evoked potentials, indicating nonfunction of the brain stem; and (c) cessation of blood flow to and through the brain (Sabom, 1998, p. 49). Yet Reynolds' near-death experience continued during clinical brain 
death, contradicting the dying-brain hypothesis that the experience should "stop when the brain's activity stops" (Blackmore, 1993, p. 4).

Another answer challenges the premise of the question. Perhaps the recollections do not in fact derive from the time of the near-death conditions. Perhaps these purportedly highly conscious "perceptions" can be accurate because the perceivers were conscious. Their perceptions might actually have been projections constructed from informational stimuli of a time period mainly prior to or following the time of near-death, while the person's mental functioning was unimpaired. Building from these pre-event or post-event perceptions (or from during-the-event auditory stimuli), the person might then have mentally fabricated an "experience" and attributed it to the NDE (Blackmore, 1993; French, 2001; Hyman, 2001).

The post-event version of this second answer hypothesizes that the "experience" was retrospectively projected from details mentioned afterward. For example, Reynolds might have heard about the details of her operation from medical staff or records (Hyman, 2001). Such a possibility is unlikely, since idiosyncratic details are "not what would likely be explained to a patient recovering from a cardiac arrest" (Sabom, 1982, p. 114). Indeed, Reynolds was given only a five-page summary of the operation, which made no mention of the idiosyncratic details that she accurately reported concerning the appearance of the cranial saw and instrument case, surgery team conversation, and so on (M. Sabom, personal communication, September 20, 2002). Generally, cardiac patients might be told

that their "heart stopped beating" and that an "electrical shock" was used on the chest to stabilize cardiac rhythm, but there is no conceivable reason to supply the details reported in the typical autoscopic NDE - the insertion of a plastic airway, the checking for a carotid pulse or pupillary response in the eye, the drawing of arterial blood from the hand or the groin, the movement of the needles on the face of the defibrillator, etc. (Sabom, 1982, p.114; see also Cook, Greyson, and Stevenson, 1998; Ring, 1980)

The pre-event and auditory versions of the fabricationist explanation posit that the apparent recollection derives from having seen pertinent people, objects, or actions prior to losing consciousness and from having heard things even while unconscious, inasmuch as the auditory sense often does persist even as consciousness is lost. Could not an experiencer actually have had pertinent prior information, heard certain events, and then on that basis fabricated or elaborated an "experience"? The pre-event and auditory fabrication hypothesis 
has difficulty in cases where the reported details were not initially in view and were never known or discussed (Sabom, 1998). Most of the details reported in Reynolds' case were of this sort.

One further evidential point counts against the fabricated-recollection hypothesis. Sabom was especially interested in Reynolds' recollection of one idiosyncratic detail in particular, namely, that one of her blood vessels was too small for connection to the cardiopulmonary bypass machine. During the procedure, Reynolds was fitted for molded speakers in her ears that "occlude the ear canals and altogether eliminate the possibility of physical hearing" (Sabom, 1998 , p. 184). Therefore, Reynolds could not have physically heard this comment during the operation. Furthermore, she reported the comment at the appropriate point:

Pam stated that she did not hear or perceive anything prior to her out-of-body experience, and that this experience began with hearing the bone saw. At this point in the operation, she had been under anesthesia for about 90 minutes. ... [The use of] the bone saw was simultaneous with the conversation about Pam's small blood vessels and, as it turns out, with her out-of-body experience. This correspondence of Pam's recollections from an out-of-body experience with the correct bit of intraoperative conversation during a six-hour operative procedure is certainly intriguing evidence. (Sabom, 1998, p. 185)

\section{Reality and the NDE: A Conclusion}

The NDE is currently a challenging anomaly. Although they assumed that an adequate psychobiological explanation would eventually be forthcoming, Dieter Vaitl and his colleagues concluded that at present "no single approach is able to account for all of the features of near-death experiences" (Vaitl, Birbaumer, Gruzelier, Jamieson, Kotchoubey, Kübler, Lehmann, Miltner, Ott, Pütz, Sammer, Strauch, Strehl, Wackermann, and Weiss, 2005, p. 102; see also Greyson, 2000). Parnia and Fenwick (2002) concluded from a research review of cases of cardiac arrest that the NDE may point to the need for a new science of consciousness. Similarly, I conclude that the phenomenon may point to a deeper reality of human existence. Although contextual and subjective factors influence the interpretation of the experience, the NDE cannot be reduced entirely to projection, interpretation, and particular context. Particular cultural and other schemas are invoked but do not seem quite adequate to describe the experience. Despite bafflement or communicative frustration, experiencers recollect heightened 
awareness and clarity and interpret their experience as real, insisting that their experience was neither dream nor hallucination. There is a remarkable degree of accuracy to autoscopic perceptions, and there are reports of indirect empirical confirmation even for some transcendental perceptions. The experience is more likely and more extensive to the extent that the experiencer was close to physical death. The accuracy and clarity of the experience are unlikely to be attributable to projections fabricated from information gained when mental function was unimpaired prior or subsequent to the near-death event, or from auditory information during the event. Most astonishing is the case of Reynolds, whose near-death experience occurred despite the documented cessation of brain wave activity. Although a definitive conclusion would be premature, the likelihood that the NDE indicates a deeper reality of human existence prompts us to ponder its possible implications for spirituality and Christianity.

\section{Spiritual Significance}

As noted, near-death survivors who have had NDEs (even compared with near-death survivors who have not had NDEs) become more spiritual. The deeper the NDE, the greater its subsequent spiritual impact, specifically in terms of "showing love and accepting others" (van Lommel, van Wees, Meyers, and Elfferich, 2001, p. 2042). Melvin Morse (Morse and Perry, 1992) argued that the key feature in the "deep" NDE accounting for subsequent spiritual, personality, and moral transformations, as well as certain impressions regarding the spiritual essence and interrelatedness of humanity, is the encounter with the light. The deep and dramatically transforming NDE of a man named Tom Sawyer provides a case study (Farr, 1993; Gibbs, 2003). Not only the light but also the life review featured prominently in Sawyer's report of his NDE.

On May 23, 1978, in Rochester, New York, Sawyer, a 33-year-old father of two boys, was crushed under his truck and had an NDE. Sawyer was working under his truck when a support gave way; the frame of the truck depressed the center of his chest, rendering him unable to breathe. He lost consciousness and his heart stopped beating. He then

had a feeling of absolutely, positively, waking up, very quickly and sufficiently. ... All pain and pressure [were] gone. I felt I could see 
very clearly, but the problem was I saw nothing but absolute, total blackness. ...

I had the desire to look around inquisitively. What is this place? Where am I? Instantaneously [with my questions], this darkness took the shape of a tunnel. It was very vast. ...

The next thing is that way, way off in the distance - to infinity there appeared this little speck of light. That light was very special; it was ... extremely bright. ..

It was utter beauty. The light ... got larger as I got closer to it. ...

There were such feelings of warmth and love coming from the Light that it made me feel good. (Farr, 1993, pp. 25-28)

Although Sawyer communicated with the light, the communication was not in words:

Instantaneously it emanated to me, thought-pattern to thoughtpattern....

As I thought of and formulated a desire or a question, it would already have been recognized, acknowledged, and therefore answered. (Farr, 1993, p. 28)

Sawyer interpreted the light as divine (specifically, as Jesus), although he found adequate description difficult:

There are characteristics and aspects of that part of my experience that I would really wish to talk about a little deeper. I've not found the words. ... Some of the things are regarding the aspect of, "What is the Light?" Well, the light is God. And what is God? God is unconditional love. God is total beauty. God is everything! (Farr, 1993, p. 38)

Sawyer then experienced a review "from the first breath of [my] life right through the accident" (p. 35). He saw and relived the events simultaneously from multiple perspectives: (a) as his adult self, observing the events "from a third-person viewpoint" (p. 37) looking down at the scene; (b) as his self at the time; and (c) as another person involved in the event. For example, he reviewed an altercation he had had as a teenager with a man who had darted in front of his truck in the street. The man had almost made contact with Sawyer's truck: "Now my attitude in those days was, God forbid that you should put even a smudge on my truck. A smudge made me furious" (p. 32). In the course of the original altercation, the man swore at and slapped Sawyer, which "instantly gave me license to annihilate this man. ... I almost killed that man" (p. 32). Sawyer was observing and being not only himself at the time (at age 19) but also the other person. He experienced

Tom Sawyer's fist come directly into my face. And I felt the indignation, the rage, the embarrassment, the frustration, the 
physical pain. ... I felt my teeth going through my lower lip - in other words, I was in that man's eyes. I was in that man's body. I experienced everything of that inter-relationship between Tom Sawyer and that man that day....

Okay. He hit me first. Try that in your life review! (p. 33; italics added)

Sawyer wanted to stay with and indeed enter the light. Nonetheless, just as he was "becoming homogeneous" and experiencing "total knowledge" (p. 38) with the light, he "reversed through the tunnel" (p. 40) and reentered his body. Immediately after reentering his body, he regained consciousness and could again breathe as the truck was lifted. After a brief hospitalization, he recuperated at home.

In retrospect, Sawyer described himself as having changed after the accident "from a [self-]righteous, self-motivated person to a spiritually motivated individual who now prioritizes helping others" (p. 60). His wife Elaine recalled that, before the accident, he was verbally and even physically abusive to her ("stupid" was one name he had called her), threw shoes and other nearby objects at her, and was very controlling, precipitating a separation at one point. Sawyer corroborated his wife's recollection: "I was the head of my family and I would tell them [Elaine and their two sons] what they could do!" (p. 94). He was "blind to her needs" (p. 95) and, to some extent, the needs of the family. He would have "a fit" upon learning that she had listened to classical music (which he did not listen to) on his radio when he wasn't home: "On my radio, she was only to listen to my music" (p. 94).

Again, following his NDE, Sawyer was transformed. His selfcentered attitudes, rages, and abusive behavior were replaced by an attitude of love and a priority on helping others. As his wife put it: "All of the sudden, he was a different person. He loved everybody!" (p. 99). Sawyer's love and altruism included humanitarian concerns: in 1980, several years after his experience, he began to speak against the planetary dangers of chemical pollution and global warming. Particularly relevant to Sawyer's new sense of love and care were the light and life review features of his NDE. At the heart of the impact of these features may be a profound sense of human interconnectedness.

\section{Significance of the Light}

The light is often interpreted as divine. Reynolds reported that she asked figures in the light, "Is the light God?" The metaphorical reply she received was, to use a theological term, panentheistic (see 
below): "No, the light is not God. The light is what happens when God breathes" (Benz, 2001). Particular interpretations of the light seem to reflect to some extent one's cultural and religious context. Sawyer's interpretation of the light specifically as Jesus Christ is a case in point. Although he had become an agnostic by the time of his accident, his religious background was Roman Catholic. Sabom (1998) found that traditional or conservative as well as liberal Christians are more likely to interpret the light as Jesus than are experiencers from other faiths.

Sabom cautioned against a literal interpretation of the light as a direct or actual encounter with God, noting "the biblical view that one cannot directly see God and live" (1998, p. 206). Indeed, citing the Bible as "our only reliable yardstick" or "objective measure" (p. 222), Sabom suggested that interpreters of the light as Jesus may have been duped by masquerading "evil angels" (p. 221) bent on destroying the experiencer's soul. Yet these destructive angels evidently tolerate the typical NDE aftereffects of love and constructive caring.

In any event, spiritual aftereffects of encounters with the light do not seem to entail a specific religious direction. Although some NDErs report an increased interest in Eastern faiths (Ring, 1984), those who were traditional (or liberal) Christians generally remain so afterward (Sabom, 1998). The general effect seemed to be a movement beyond superficial activities or preoccupations and toward profound love as well as an "intrinsic faith," as illustrated in an NDEr's comment that after his experience he "no longer had time for the little country club things that go on in the churches" (Sabom, 1998, p. 88).

\section{Significance of the Life Review}

Although Sawyer attributed a "good" feeling to the "warmth and love coming from the light" (Farr, 1993, p. 28), he seemed to derive particular moral insights and inspiration from his life review:

Will you be totally devastated by the crap you've brought into other people's lives? Or will you be equally enlightened and uplifted by the love and joy that you have shared in other people's lives? ...

You will be responsible for yourself, judging and reliving what you have done to everything and everybody in very far-reaching ways. (Farr, 1993, p. 34)

David Lorimer termed life reviews such as Sawyer's empathetic life reviews, "in which people relive events through the consciousness of the person with whom they were interacting at the time" $(1990$, pp. 12 ). Lorimer documented and described several cases of initially rather 
self-centered individuals who nearly died, encountered a loving light, and experienced an empathetic life review (one individual exclaimed, "I was the very people that I hurt, and I was the very people I helped to feel good," p. 21), and dramatically transformed into persons who loved and attempted to help everyone. In addition to the light, then, the empathetic life review (typically in the presence of the light) seems to contribute to dramatic changes in people away from superficial and self-centered attitudes or self-serving distortions and toward love and care for others, even strangers.

Indeed, when asked what had been the hardest thing for her to deal with in her marriage with Sawyer, his wife mentioned not the old husband but the new one! Her response was surprising. After all, whereas Sawyer had previously abused, demeaned, and controlled her, after his near-death experience he "was suddenly seeing her in a different light" (Farr, 1993, p. 98), loving her as a precious human being, a person in her own right. Recall, however, that now Sawyer had a humanitarian scale of love. Again, in his wife's words, "He loved everybody!" Everybody was precious; to some extent, his wife was for a time no longer particularly special. To illustrate the problem, she mentioned that when she was ill once and needed him to help her, he was not in a position to because he was "on the phone helping someone else" (Farr, 1993, p. 94). Nevertheless, both of them have adjusted and remain married (T. Sawyer, personal communication, July 29, 2005).

\section{Interconnectedness of Humanity}

Sawyer's profound sense of a humanity continuous with the allencompassing, loving light of God, of a profound interconnectedness such that the effects of one's actions are "far-reaching" and "everyone is precious," is not uncommon among NDErs, especially those with "deep" experiences such as his. Reynolds, the NDEr described earlier, suggested that, although "everyone has a different tone," the "beauty is in the harmony" (Benz, 2001). An African-American youth in St. Louis who had nearly drowned realized in his experience the superficiality of skin color, indeed, that humanity in all its diversity is "in the light." Accordingly, he no longer "puts people down":

I struggled to breathe and then I couldn't do it no more. . . Then I just floated out of my body into a safe place. It was all bright; I felt peaceful.

Suddenly, I realized that we are all the same. There ain't no black 
and there ain't no white. I saw that bright light and I knew it was all the colors there were, everything was in that light. ...

I felt better about myself. I know that I am different. I don't think about putting people down for fun like I used to....

I see life the way it really is. It is not meant to be played with. (Morse and Perry, 1992, pp. 17-18)

Again, it is not uncommon for NDErs to have such impressions of all-encompassing divinity and love in the light, and an interpenetrative emotional connection with others in the life review. Sawyer's reported instantaneous or telepathic communication during his NDE is also not uncommon. After returning, they may express a stronger belief in life after death, a reduced interest in self-aggrandizing status or material things, a sense of divine presence and intrinsic faith, an expansive love, a remarkable insight into the problems of others, and a sense of the far-reaching ramifications of one's actions. Furthermore, they may effect corresponding changes in lifestyle. Lorimer suggested that NDErs seem to access a deeper reality wherein the whole of nature is understood as "an interconnected web of creation ... in which we are interdependent strands" (1990, p. 22). Lorimer further suggested that the NDE with its implication of underlying interconnectedness should be used as the "empirical soil" (p. 1) for a vitalized ethic of profound love and universalized ideal or "Golden Rule" reciprocity. Arthur Deikman (1996) argued that the awareness of underlying connection must supplant - and supplant soon - the selfcentered mentalities and ethnocentric ideologies that increasingly threaten the very survival of human life, indeed, the very habitability of our planet.

\section{Nonlocality and Individual Differences in Spirituality}

To claim that human beings, despite their diversity, may nonetheless in some ultimate sense all be continuous with the light of divine love is not to claim that humans always sense and live by their spirituality of love and connection. In short, people are not gods. One can scarcely claim, for example, that the old Tom Sawyer (or even the new one, for that matter) was divine. To claim that people are integral to the light is to claim, however, that there is more to human life than existence in this material realm, that people are ultimately spiritual. In this light, NDErs may have glimpsed a deeper reality, albeit filtered through cultural and personal context. Intriguingly, they attribute subsequent spiritual, moral, and personality transformations to their 
experience; and the deeper or more extensive the "glimpse," the greater the impact of love and connection.

One might make an analogy with the seeming discontinuity between the macro- (local) and micro- (nonlocal) scales of physical reality. One implication of quantum theory and Bell's theorem is that our phenomenal macro- world of separate parts that interrelate in linear time and dimensional space is supported by a "nonlocal" realm of immediate interconnectedness, an underlying reality that Roger Penrose called "profound, timeless, and universal" (1994, p. 413; see also Aspect and Grangier, 1986; Bell, 1996; Bouwmeester, Pan, Mattle, Eibl, Weinfurther, and Zeilinger, 1997; Herbert, 1985). These nonlocal underpinnings are not entirely divorced from our local world, however; macro-scale devices such as superconductor rings demonstrate quantum effects, indicating in the final analysis a continuity from the local to the nonlocal (Lindley, 1996).

Correspondingly, in human reality, perhaps our phenomenally local world of separate selves is not entirely divorced from a supportive nonlocal realm of connections that are "unmediated, unmitigated, and faster than light" (Herbert, 1985, p. 227). One is reminded of the instantaneous or telepathic communication reported by Sawyer during his NDE. Although human individuals may ultimately integrate with a divine spiritual reality, and although spiritual effects are sometimes seen in phenomena such as the NDE, most humans are far from divine in this local world of ostensibly separate selves. All too evident are our egocentric biases, desires, and motives - modern parlance for our proneness to sin. Fortunately, we are capable of moral growth through social "decentering" from our self-centered tendencies as we take and consider the perspectives of others (Piaget and Inhelder, 1969). We even achieve profound moral perception from time to time. Just as the parts of physical reality are ultimately continuous with nonlocal underpinnings, we current inhabitants of this local world of seemingly separate and independent selves are not entirely divorced from our deeper interconnected spirituality - a resonance with the nonlocal suggested by the experiences not only of NDErs but also of mystics, meditators, and poets (Gibbs, 2003).

Can humans be so egocentric or self-centered as to become separated from the light? Although the potential for continuity may remain, an atypical type of NDE would suggest that discontinuity is in effect possible: Humans can cut themselves off from their spirituality of love and connection. As noted, Sawyer in his NDE initially experienced the "problem" of finding himself in "absolute, total blackness." For him, 
this problem dissolved as he then began to move with increasing speed toward a loving, extremely bright, "very special" light. For others, however, the negative experience continues. Among the relatively rare (or underreported) "distressing" (Greyson and Bush, 1992), "frightening" (Bush, 2002), or "less than positive" (Rommer, 2000) versions of the NDE, one category pertains to the experience of a continuing void or realm of total blackness. The experience typically engenders a sense of "loneliness, fear, desolation, alienation, and separation" (Lorimer, 1990 , p. 86). Barbara Rommer (2002) suggested from her study of such cases that the distressing NDE can be a "blessing in disguise" (the title of her book), insofar as it can serve as a wake-up call.

What is the referent for this experience of separation? Separation from what? Is it from other humans in the interconnected web of creation? From the spiritual source or essence of one's self? From communion with the divine? If, as the St. Louis youth cited above put it, we are all part of the light, then all of these referents may apply. Such separation would seem to qualify the impression that all humans are continuous with a realm of spirituality and divine love. Perhaps some individuals have become so self-centered, self-serving, selfrighteous, cognitively distorted, and controlling of others as to isolate themselves, to cut themselves off from their spirituality for all intents and purposes. Spiritual isolation is the hell of darkness and distortion. Intriguingly, without reference to the NDE literature, Spong wrote along these same lines:

One separated from ... love ... is finally separated from God. Beyond fiery pits, brimstone, devils, which are nothing but literalized attempts to describe the deepest human pain, there is hell. ... Hell is the ... loneliness of isolation. ... it is ... darkness. $(1980$, p. 221)

Perhaps the distressing NDE at least sometimes represents an endpoint in a range of individual differences in the blended continuum (as Spong put it) from the egoistic human to the divine. If there are individual differences in the threshold for the so-called mind-brain split, then perhaps there are also individual differences in suffusion with spirituality, from a phenomenological separation induced by total self-centeredness and distorted worldview to having a deep sense of divine presence and connection with others.

\section{Implications for Christianity}

Having considered the NDE with its ontological and spiritual significance, we are now in a position to consider its implications for 
Christianity and the writings of Spong. In light of what the NDE seems to be telling us about humanity and spirituality, how are we to understand Jesus? Do the commonalities between NDErs and Jesus miss a basic discontinuity between humans and divinity? Or do they lend credence to Spong's continuity view? To address these questions adequately, we must first consider Spong's work. Why doesn't Spong accept the traditional Christian view of Jesus? Why does he call for a new Christianity?

\section{Spong's New Christianity}

That Jesus was a profoundly spiritual person - but still a person (defined as a spiritual being having a human experience) - is the premise of the new Christianity called for and envisioned by Spong. In Spong's view, Jesus was so "blended" with divinity that those who interacted with him experienced in his presence the "unflagging and unconditional" love of God (Spong, 1996, p. 48). This continuity view of Jesus emerges, according to Spong (1996), once we "liberate" Jesus from a literalist misunderstanding and misrepresentation of him as external divinity incarnate, the promised Messiah and sacrificial lamb, different from others not in degree but in kind. The traditional discontinuity view of Jesus has its origins, according to Spong, in the theistic worldview common to early peoples as well as, in particular, the framework of Jewish sacred history. Stories about Jesus crafted within that framework for liturgical purposes came to be taken literally as eyewitness reports.

\section{Assimilating Jesus to Theism and Jewish Sacred Heritage}

Any new experience, if it is to be meaningful, must be seen to some extent through the lens of a preexisting framework or schema of images, thoughts, and words. The experience activates one or more schemas, to which the experience is then assimilated (Piaget, 1967/ 1971). I argued above that the content of the NDE is extensively influenced by the cultural and personal schemas (or, more broadly, contexts) of the experiencer. Spong made a similar argument with reference to the content of the Bible. If Jesus was indeed profoundly spiritual (albeit still a human being), then his divinely loving and caring presence must certainly have represented a new experience for 
his fellow Jews. How could the Jews of biblical times understand this new experience?

The worldview available to Jews of biblical times and other early peoples was "theistic," in terms of which God was "a being, supernatural in power, dwelling outside this world and invading the world periodically to accomplish the divine will" (Spong, 2001, pp. 2122 ). In the various religious traditions of diverse regions of the world, a discontinuity view of God was pervasive:

The theistic God was always other, always external to the self who was defining the God-figure, always supernatural. ... The theistic God was also presumed to be the explanation for that which was beyond rational understanding, a being capable of miraculous power who therefore needed to be supplicated [for example, through ritual animal sacrifice], praised, obeyed, and pleased. (Spong, 2001, p. 490)

Furthermore, "almost every religious system" of early peoples, in a theistic extension of ethnocentrism, "asserted that its particular deity was the only true and real divine being" (p. 52).

Given this framework of theism, Jesus' profound spirituality was seen as "the result of an external deity who had somehow entered into him" (Spong, 1998, p. 125). The time of entry was varyingly placed at Jesus' Resurrection (Romans 1:3, 4), baptism (Mark 1:9-11), or conception (Luke 1:31-32; Matthew 1:23), or in the realm of eternity (John 1:1-14) (Spong, 2001).

In addition to applying the early human framework of theism, those who encountered Jesus also had available the religious schemas of Jewish history. "Jews filtered every new experience through the corporate remembered history of their people, as that history had been recorded in the Hebrew scriptures of the past" (Spong 1996, p. 37). Accordingly, over decades, the Jews who had encountered God's presence in Jesus progressively

wrapped around their descriptions of Jesus' words and deeds the narratives of their own religious past. When they confronted what they believed was the presence of God in a contemporary moment, they interpreted this moment by applying to it similar moments in their sacred story.... So the Gospels were. ... interpretations of who Jesus was based on their ancient and sacred heritage. (p. 20)

These interpretations, first oral and then written, developed in the context of first-century Jewish religious politics:

Within the synagogues of the Jewish people from the year 30 to the year 70 resided some of their brothers and sisters who had come to 
believe that God had acted in Jewish history in a new way in Jesus of Nazareth. (p. 46)

Accordingly, the God-presence in Jesus was interpreted in terms of ancient prophecies of a coming Messiah or sacrificial lamb for the Jewish people and all humanity. Oral stories about Jesus began to gain written form. The first Gospel, Mark, "was written under the domination and influence of the Jewish liturgical calendar" (Spong, 1996, p. 77): "Various portions of Mark's Gospel that tell the Jesus story appear designed to be read during the Jewish observances of New Year, Atonement, Tabernacles, Dedication, and Passover" (p. 85). Especially, "the passion story was the Christian Passover story. Jesus was the new paschal lamb" (pp. 71-72). Another early part of the New Testament, the Epistle to the Hebrews,

clearly portrayed Jesus as the sacrificial lamb of the Day of Atonement. ... It suggested that Jesus had entered the heavenly realm in much the same way that the sacrificial animal went up to God. (p. 229)

Tension grew between Orthodox Judaism and this nascent movement of oral and written belief in Jesus as the new paschal lamb. Facilitating the advent of literal Christianity was the Romans' destruction in 70 A.D. of the city of Jerusalem, including the temple of the high priests:

The resultant loss of a Jewish national identity created a crisis of significant proportions among the most traditional adherents of the religion of Moses and the prophets. This meant inevitably that the tension between Jewish Christians and the more orthodox Jewish faith tradition increased dramatically. (Spong, 1996, p. 49)

The writings continued. Matthew and Luke built upon the Marcan theme of Jesus as the fulfillment of the law and the prophets. Toward this end, Matthew even refined numerous passages from Mark, and added details compatible with prophecies of a promised Messiah in the Hebrew scriptures. (Other New Testament scholars, such as James Dunn [1985], have offered detailed textual analyses of apparent theological corrections across the synoptic Gospels, for example, of Marcan passages in Matthew.) The theistic and prophetic interpretation of Jesus' death "in terms of Jewish ritual sacrifice was ... carried to new heights" (Spong, 1996, p. 50). The Christians "argued, to the consternation of [the] orthodox traditional Jews, that the Hebrew scriptures found their only fulfillment in the Messiah Jesus, and that apart from him there was no value in that rich sacred past" (p. 51). 
Spong speculated that the final break of this nascent movement of Jewish Christians from their orthodox peers may have come in the late 80s A.D. As reflected in the last Gospel (John 9:22, 12:42), Jewish Christians found themselves "excommunicated from synagogue life and ultimately from Judaism" (Spong, 1996, p. 53). And for their part, the nascent Christians began to reject all things Jewish. They eschewed the Jewish liturgical context and purpose for the Gospels and began "to ascribe to these books an accuracy about historical facts and a literalness about the events being described" (p. 53). Indeed, the putative Gospel writer John claimed to have given an eyewitness account (John 21:24). Spong dismissed that claim as implausible, given that the author would have to have been "almost 100 years old when he wrote - hardly a possibility in the first century" (Spong, 1996, p. 68).

\section{The "Authentic" Jesus: Spong's Analysis and Continuity View}

As noted, the meaningful perception of any new experience requires the activation of appropriate schemas or frameworks for interpretation. Yet to be adequate or veridical or growth-inducing, the new experience cannot simply be assimilated to those schemas. If there is to be learning or development, that which cannot readily (and veridically) be assimilated to the old and familiar must be noticed, attended to, dealt with in some way. Many NDErs have struggled to find the words to describe the anomalous qualities of their experience, and to transform their lives in its light. With reference to the New Testament, Spong claimed that the "authentic" or original historical Jesus can be discerned despite the discontinuity interpretation of Jesus' God-presence derived from theism and Jewish heritage. To use Piagetian terms, the New Testament writers not only assimilated but also achieved some "accommodation" to the new experience that was Jesus. Accordingly, through thematic scrutiny of their efforts, we can (according to Spong) disembed from the theistic external "God claims" something of the authentic Jesus.

Spong's analysis focused on Jesus' expansive, humanity-wide love as the authentic core of Jesus' significance. He "was constantly dismantling the barriers that separate people from one another," and "calling those around him to walk past their tribal fears" (Spong, 1998, p. 131):

Beneath the God claims made for this Jesus was a person who lived a message announcing that there was no status defined by religion, by tribe, by culture, by cult, by ritual, or by illness that could separate 
any person from the love of God. If love is a part of what God is or who God is, then it can surely be said of this Jesus that he lived the meaning of God. ... (p. 125)

Other aspects of Jesus also captured "people's attention":

He possessed an unearthly capacity to be present, totally present, to another person. ... [And he was] a remarkably free man. He was free to forgive, free to endure, free to be, and free to die. His being was not distorted by his external circumstances. (pp. 125-127)

So inspiring in his "unearthly" presence and love, Jesus cultivated the human potential for spirituality. Hence Spong's continuity view: "Human life is capable of entering the infinity of God because the infinity of God can be found in the heart of every human life. The two are not distinct. Humanity and divinity flow together" (Spong, 1998, p. 131). Despite the human tendency to be self-centered and selfserving (Spong, 1973, 2001), persons can strive (in various ways and with various degrees of success) to reach and be touched by the infinite love of God: "That is [what] the Johannine writer was trying to say when he asserted that 'God is love, and whoever abides in love, abides in God' (I John 4:16)" (Spong, 1998, p. 131).

An important question is whether Spong's analysis and continuity view captured "the original Jesus or Spong's Jesus" (W. Bendschneider, personal communication, May 8, 2005). Sabom argued that Spong's depiction represented merely "another example of picking and choosing some parts of Jesus which correspond with his personal likes and dislikes, and summarily dismissing other parts which don't fit into his personal scheme of things" (M. Sabom, personal communication, April 23, 2005). Was Spong's analysis well-reasoned and compelling, or subjective and arbitrary? My own impression is that Spong made a plausible case for his depiction, although he may have underestimated Jesus' paranormal abilities, as I will discuss below.

\section{Beyond Theism}

Just as Jesus must be disembedded from Messianic literalism, Christianity in Spong's analysis must be liberated from the supernatural theism of antiquity. The process may not be easy. Consider, for example, Jesus' death on the cross. What is Christianity without the cross of atonement? If God is love, what greater evidence is Christ's sacrifice? Traditional Christianity may owe much of its inspirational power to sacrificial love; just consider the prominence of sacrificial love 
in so much of the world's greatest literature. Yet upon reflection, sacrificial love as applied to the crucifixion implies a less than loving God. "A human father who would nail his son to a cross for any purpose would be arrested for child abuse" (Spong, 1998, p. 95). Crucifixion as "a divinely required human sacrifice" sounds "quite strange to modern ears" (Spong, 2001, p. 123). Particularly strange is the implied

image of God. This is a deity who acts like a Middle Eastern potentate who cannot forgive until his offended dignity has been satisfied. This deity cannot be moved to embrace [his] fallen creatures without the sacrifice of a human being, [a] blood offering. (p. 123)

Theistic systems of belief are typically closed systems of doctrine whose proponents seek to "stifle debate with ex cathedra pronouncements" (Spong, 1998, p. 54). The trial of Galileo is perhaps the most famous example in church history. The stifling of scientific knowledge, however, can last only so long. With advances of science and scientific explanation, the "arenas reserved for God alone" have been shrinking and theism has been fading:

Every new discovery about how the natural world operates cuts into the arena once reserved for God alone. The theistic God first became the gap-filler, explaining those things that human knowledge could not. The gaps, however, grew fewer and fewer with each century, and more are being closed every day by the advance of knowledge. (p. 53)

The fading of theism may permit more adequate understandings of the divine to take hold, and along with it an openminded inquiry that contrasts refreshingly with the implicit (and at times, explicit) arrogance and theocentric imperialism that seem to come with the territory of theism. In traditional (especially, Protestant) Christianity, "salvation requires 'accepting Jesus as one's personal savior'. ... Heaven is thus reserved for those who can assert that this kind of conversion is part of their personal story. Lostness [or hell] awaits all others" (Spong, 2001, p. 172). The reference to Jesus as God's "only son" implies

that none of the other religious systems of the world can offer its people a point of connection with the divine. Many Christians have made exactly that claim, and its effect for centuries has been to fuel a quite unholy attitude of religious imperialism. (p. 11)

Although the Church has had positive moments, it

has also had in its history some rather dreadful moments marked by such things as "holy" wars, "sacred" crusades, inquisitions 
[featuring the burning of critics at the stake], inhumane antiSemitism, and an overt, killing racism, sexism, and homophobia. (Spong, 1998, p. 17)

It is the deity of theism who is "alleged to have supported" such horrors in order "to impose a particular version of divinity on other people" (Spong, 2001, p. 230). Theism, then, readily subverts God's love into prejudice at best, mass murder and torture at worst. If the worst betrayals of God's love by the church emanated from the theistic worldview, then the fading of theism can scarcely be lamented.

\section{Panentheism}

Fortunately, the fading of theism does not leave atheism as the only alternative in questions of God and reality. Other faith and mystic traditions exist that are neither theistic nor atheistic but "panentheistic," meaning loosely that the divine "is found at the depths of life, working in and through ... this world" (Spong, 1998, p. 62). Marcus Borg pointed to a panentheistic theme

in the Bible. Its clearest compact expression is attributed to Paul in the book of Acts: God is the one in whom "we live and move and have our being." ... God is more than everything, even as everything is in God. ... Combining [transcendence and immanence] produces the central claim of panentheism: God is "the More" who is "right here." (2003, p. 66)

In the study of panentheistic themes in other traditions lie opportunities for growth. Just as the individual to grow must decenter from self by taking the perspectives of others, Spong (2001) suggested that Christianity must decenter from its "self"-centeredness: "We do not possess the sole pathway to God, for there is no sole pathway" ( $p$. 179). Furthermore, "the idea that Jesus is the only way to God or that only those who have been washed in the blood of Christ are ever to be listed among the saved, has become anathema and even dangerous in our shrinking world" (p. 179).

Especially helpful to decentering (whether by the individual or the church) is the exploration of Buddhist and other Eastern faith traditions. Through such exploration, we can come to realize "that our ancient Western definitions of God do not exhaust the reality of God" (Spong, 2001, p. 58). Buddhist thought, for example, is deeply spiritual; yet "nowhere in classical Buddhism do the Buddhists posit the existence of an external deity" (p. 57). Spong referred to his dialogues, for another example, with Hindu scholars: "They had not 
been shaped by the one I call Christ, but I did not doubt that they had been shaped by the God that I have met in Christ" (2001, p. 183). Moreover,

to the extent that the Buddha, Moses, Elijah, Krishna, Mohammed, Confucius, Julian of Norwich, Catherine of Genoa, Hildegard of Bingen, Rosa Parks, Florence Nightingale, Mahatma Ghandhi, Martin Buber, Thich Nhat Hahn, Dag Hammarskjold, or any other holy person brings life, love, and being to another, then to that degree that person is to me the word of God incarnate. (Spong, 2001, p. 145)

Not only Christianity but all religions should "separate the wheat from the chaff of [their] tradition" (p. 182) so as to achieve social and religious decentering:

My hope is that my brothers and sisters who find Judaism, Islam, Hinduism, or Buddhism as their point of entry, based upon their time and place in history, will also explore their pathway into God in a similar manner, until they too can escape the limits of their tradition.... Then each of us ... can reach across the once insuperable barriers to share as both givers and receivers in the riches present in all human sacred traditions." (Spong, 2001, p. 182)

Jesus, who "crossed every boundary of tribe, prejudice, gender, and religion" (p. 182), will be honored when and if such a day of sharing arrives. The new Christian faith community "would not seek to propagandize people by claiming that it has all the answers" (p. 214). Rather, Spong's envisioned new Christianity would be an open system, growing through inquiry and dialogue. Indeed, "any recasting of the creeds that we might produce today will be no more eternal than those formulations of the fourth and fifth centuries proved to be, nor should they be" (Spong, 1998, p. 19).

\section{Conclusion: The NDE and Spong's New Christianity}

Spong's argument, then, is that a new Christianity is needed for the modern world. The "new" Christianity would be faithful to the vision of the original Jesus, who (according to Spong) intended his movement "to be a radical, transforming, boundary-breaking religious system," one that would call "people to enter the experience of non-tribal humanity" (Spong, 2001, pp. 132-133). To be a disciple of Jesus would be to "imitate this God presence by living fully, loving totally, and 
having the courage to be all that God has created each of us to be" (Spong, 1996, p. 333). The "only mission" of the disciple of the authentic Jesus is to make

it possible for everyone else to live, to love, and to be.... Our task is not to convert; our task is to call people into the depths of their own capacity to be. (Spong, 1998, pp. 218-219)

To fulfill the true "gospel message" (Spong, 2001, p. 132) of noncoercive and universal love and encouragement, then, Christianity must disembed from its premodern worldview of theism and recognize the liturgical, nonliteral context of the Gospel stories.

To summarize Spong's critique of traditional Christianity: Twenty centuries ago, certain Palestinian Jews made sense of the God presence they experienced in Jesus by invoking the theistic and Messianic framework of their sacred heritage. God must have entered Jesus to fulfill the prophecy of a saving Messiah, a human sacrifice to redeem them by dying in substitutive atonement for their sins. This God was perceived as basically discontinuous from and external to humanity. Discernible through the theism and literalism of Palestinian perception, however, is a profoundly spiritual person.

Theism naturally tends to be theocentric; and Christianity must decenter. Helpful to decentering will be the courage to reach out to and learn from other traditions - traditions whose thoughtful adherents, Spong hoped, will at the same time be undertaking their own disembedding and decentering processes.

The NDE research and Spong's work, as well as that of Tillich and others, are different approaches, limited in different ways; that they nonetheless point in the same direction suggests a validity to the spiritual view of human existence. People can be viewed as primarily spiritual beings having human experiences, ranging from selfcenteredness and destructive isolation, to love and constructive connection, to glimpses and impressions of spiritual reality. Persons who have had NDEs return with a greatly reduced fear of death, which they attribute to an impression in their experience of a deeper reality of human existence in general and of their existence in particular. That their impression is not entirely reducible to subjective imagination or brain states is suggested by evidence such as accurate, specific, and idiosyncratic recollections despite (at least in one case) documented absence of brain wave activity.

In addition to stimulation from other faith traditions, stimulation from near-death research findings can contribute to decentering 
toward a new and evolving Christianity. We have noted certain "Christ-like" spiritual qualities that NDErs seem to share with Jesus himself; and perhaps there are other common qualities. Indeed, might Jesus also have had a near-death experience? The possibility sounds strange and even imperious (are we to see NDEs as relevant to everything?), but consider the more unconfirmed aspects of the NDE literature.

Some NDErs, perhaps especially those experiencers whose NDE occurred in some depth and when they were children, report more than ordinary insight into the problems of others or premonitions of future events. Some anecdotes suggest paranormal (for this world) or psychic abilities: "telepathy, precognitive feelings [or] ... dreams, seeing other people and places through some kind of remote viewing, being able to diagnose illnesses and sometimes even acting as healers" (Morse and Perry, 1992, p. 97). Knowledge of others' thoughts, remote awareness, precognition, and certainly healing are all attributed to Jesus in the Gospels. Clairvoyance and healing powers are typically also attributed to mystics, a point consistent with interpretations of Jesus as a mystic (Fanning, 2001). Although Spong may be right that the Gospels are not eyewitness accounts, these psychic elements in the Gospel stories may reflect certain additional commonalities with NDErs and ways in which Jesus was a profoundly spiritual person a point that may be granted by Spong, who wrote that "perhaps we human beings are more psychically connected than we have ever imagined" (1998, p. 145).

Like the St. Louis youth cited above, Jesus may have known from an early age that he was "different." Given the times of Messianic expectation in which Jesus lived, it would not have made Jesus a "lunatic" (Lewis, 1943, p. 56) to have interpreted his profound spirituality (including his psychic abilities) in theistic terms, to construct a Messianic identity. Perhaps precisely because of his extraordinary gifts, insights, and presence, Jesus eventually gained a following while other would-be Messiahs alluded to in the Gospels did not. Indeed, given reports of after-death communications (Guggenheim and Guggenheim, 1995), Jesus' posthumous presence traditionally interpreted as the Resurrection may have been more paranormal than Spong's (1994) phenomenological interpretation would seem to suggest. In his zeal to excise theism and literalism from Christianity, Spong may have underrepresented paranormal aspects of Jesus' spirituality.

In general, the NDE literature would seem to resonate with Spong's 
continuity view of Jesus, spiritual view of humanity, and new Christianity. Consistent with the qualities of Jesus emphasized by Spong, NDErs (especially, deep NDErs) are remarkably nonmaterialistic, experience an inner sense of divine presence, have insight into the problems of others, and express an expansive love in word and lifestyle. Various aspects of NDE research converge in pointing toward a deeper human reality of love and connection. That humans, despite varying degrees of self-centeredness and distortion, may nonetheless in some ultimate sense all be integral to the light of divine love, converges with Spong's thesis that humans are ultimately spiritual, indeed, that humanity and divinity are not discontinuous but instead blend or flow together. Suggestive of the "empathetic" life review (Lorimer, 1990) in the NDE is Spong's assertion that he or any other individual human being is "joined with the beings of others who are at one with the Ground of all Being" (1998, p. 219; see also Tillich, 1952). In the light of this deep interconnectedness, "something like ethical objectivity begins to emerge. There is an 'objective' wrongness to seeking to cause or increase the pain of another life. If I do that, I also inevitably become self-destructive" (Spong, 1998, p. 161).

Spong was emphatic that the new Christianity he envisioned was to be openminded and evolving. It would be not a Christianity of ex cathedra pronouncements, whose prominence would be achieved through the stifling (through excommunication or worse) of anyone whose perspective differed. Like Spong's new Christianity, NDE research is at least in principle openminded and evolving. Many NDE researchers, like Fenwick, Greyson, Janice Holden, Morse, Sam Parnia, Ring, Sabom, and van Lommel (all of whom have medical or academic graduate training) use the scientific method. That is, they engage in controlled empirical inquiry and describe their methods in sufficient detail that others may assess for themselves the replicability of their results. Those who survey and ponder the implications of NDE research (myself included) seek to achieve impartial or objective conclusions - and understand that the independent surveys and inferences of others may in good faith challenge those conclusions. So much the better. The resulting dialogue may effect a healthy decentering of the perspectives of each and a resulting progress toward more valid understanding. If NDErs and Jesus have in common certain spiritual qualities (evident especially in Jesus), perhaps it can also be said that NDE research and Spong's envisioned new Christianity share in principle the ideal of progress through honest and open dialogue. 


\section{References}

Aspect, A., and Grangier, P. (1986). Experiments on Einstein-Podolsky-Rosen-type correlations with pairs of visible photons. In Penrose, R., and Isham, C. J. (Eds.), Quantum concepts in space and time (pp. 1-15). Oxford, England: Clarendon Press.

Bell, J. S. (1966). On the problem of hidden variables in quantum theory. Research in Modern Physics, 38, 447-452.

Benz, G. R. (Producer). (2001). Beyond human limits [Television broadcast]. Silver Spring, MD: Discovery Communications.

Blackmore, S. (1993). Dying to live: Near-death experiences. Buffalo, NY: Prometheus Books.

Blanke, O., Ortigue, S., Landis, T., and Seeck, M. (2000). Stimulating illusory own-body perceptions. Nature, 419, 269.

Bonenfant, R. J. (2004). A comparative study of near-death experience and non-neardeath experience outcomes in $\mathbf{5 6}$ survivors of clinical death. Journal of Near-Death Studies, 22, 155-178.

Borg, M. J. (2003). The heart of Christianity: Rediscovering a life of faith. San Francisco, CA: HarperSanFrancisco.

Bouwmeester, D., Pan, J. W., Mattle, K., Eibl, M., Weinfurther, H., and Zeilinger, A. (1997). Experimental quantum teleportation. Nature, 390, 575-579.

Bush, N. E. (2002). Afterward Making meaning after a frightening near-death experience. Journal of Near-Death Studies, 21, 99-133.

Callanan, M., and Kelley, P. (1992). Final gifts: Understanding the special awarenesses, needs, and communications of the dying. New York, NY: Poseidon Press.

Cook, E. W., Greyson, B., and Stevenson, I. (1998). Do any near-death experiences provide evidence for the survival of human personality after death? Relevant features and illustrative case reports. Journal of Scientific Exploration, 12, 377-406.

Cox-Chapman, M. (1995). The case for heaven. New York, NY: Putnam's Sons.

Deikman, A. J. (1996). Intention, self, and spiritual experience: A functional model of consciousness. In Hameroff, S. R., Kazniak, A. W., and Scott, A. C. (Eds.), Toward a science of consciousness: The first Tucson discussions and debates (pp. 695-706). Cambridge, MA: MIT Press.

Dunn, J. D. G. (1985). The evidence for Jesus. Louisville, KY: Westminster Press.

Fanning, S. (2001). Mystics of the Christian tradition. New York, NY: Routledge.

Farr, S. S. (1993). What Tom Sawyer learned from dying. Norfolk, VA: Hampton Roads Publishing.

Fenwick, P. (2005). Science and spirituality: A challenge for the $21^{\text {st }}$ century. Journal of Near-Death Studies, 23, 131-158.

French, C. (2001). Dying to know the truth: Visions of a dying brain, or false memories? Lancet, 358, 2010-2011.

Gibbs, J. C. (1985). Moody's versus Siegel's interpretation of the near-death experience: An evaluation based on recent research. Anabiosis: The Journal of Near-Death Studies, 5, 67-81.

Gibbs, J. C. (1997). Surprise - and discovery? - in the near-death experience. Journal of Near-Death Studies, 15, 259-278.

Gibbs, J. C. (1999). God, tragedy, and the near-death experience: Evaluating Kushner's perspectives on theodicy. Journal of Near-Death Studies, 17, 223-259.

Gibbs, J. C. (2003). Moral development and reality: Beyond the theories of Kohlberg and Hoffman. Thousand Oaks, CA: Sage Publications.

Greyson, B. (1983). The Near-Death Experience Scale: Construction, reliability, and validity. Journal of Nervous and Mental Disease, 171, 369-375.

Greyson, B. (1992-1993). Near-death experiences and antisuicidal attitudes. Omega, 26, $81-89$. 
Greyson, B. (2000). Near-death experiences. In Cardeña, E., Lynn, S. J., and Krippner, S. (Eds.), Varieties of anomalous experience: Examining the scientific evidence (pp. 315-352). Washington DC: American Psychological Association.

Greyson, B. (2001, August). Are NDErs out of their bodies or out of their minds? Paper presented at the North American Conference of the International Association of NearDeath Studies, Seattle, WA.

Greyson, B., and Bush, N. E. (1992). Distressing near-death experiences. Psychiatry, 55, 95-110.

Guggenheim, B., and Guggenheim, J. (1995). Hello from heaven! A new field of research confirms that life and love are eternal. Longwood, FL: The ADC Project.

Herbert N. (1985). Quantum Reality: Beyond the new physics. New York: Anchor Books.

Hyman, R. (2001). Anomalous experience in a mundane world [Review of Varieties of anomalous experience: Examining the scientific evidence]. Contemporary Psychology: APA Review of Books, 46, 453-456.

James, W. (1958). The varieties of religious experiences: A study in human nature. New York, NY: Mentor Books. (Original work published 1902)

Kellehear, A. (1996). Experiences near death: Beyond medicine and religion. New York, NY: Oxford University Press.

Lewis, C. S. (1943). Mere Christianity. New York, NY: Macmillan.

Lindley, D. (1996). Where does the weirdness go? Why quantum physics is strange, but not as strange as you think. New York, NY: Basic Books.

Lorimer, D. (1990). Whole in one: The near-death experience and the ethic of interconnectedness. London, England: Arkana.

Moore, P. C. (Ed.) (1998). Can a bishop be wrong? Ten scholars challenge John Shelby Spong. Harrisburg, PA: Morehouse Publishing.

Morse, M., and Perry, P. (1992). Transformed by the light: The powerful effect of neardeath experiences on people's lives. New York: Villard.

Osis, K., and Haraldsson, E. (1977). At the hour of death. New York, NY: Avon.

Owens, J. E., Cook, E. W., and Stevenson, I. (1990). Features of "near-death experience" in relation to whether or not patients were near death. Lancet, 336, 1175-1177.

Parnia, S., and Fenwick, P. (2002). Near death experiences in cardiac arrest: Visions of a dying brain or visions of a new science of consciousness. Resuscitation, 52, 5-11.

Penrose, R. (1994). Shadows of the mind: A search for the missing science of consciousness. New York, NY: Oxford University Press.

Piaget, J. (1971). Biology and knowledge: An essay on the relations between organic regulations and cognitive processes (Walsh, B., trans.). Chicago, IL: University of Chicago Press. (Original work published in French in 1967 as Biologie et connaissance: Essai sur les relations entre les régulations organiques et les processus cognitifs)

Piaget, J., and Inhelder, B. (1969). The psychology of the child (Weaver, H., trans.). New York, NY: Basic Books.

Potts, M. (2002). The evidential value of near-death experiences for belief in life after death. Journal of Near-Death Studies, 20, 233-264.

Ring, K. (1980). Life at death: A scientific investigation of the near-death experience. New York, NY: Coward, McCann and Geoghegan.

Ring, K. (1984). Heading toward omega: In search of the meaning of the near-death experience. New York, NY: Morrow.

Ring, K., and Lawrence, M. (1993). Further evidence for veridical perception during near-death experiences. Journal of Near-Death Studies, 11, 223-229.

Rommer, B. R. (2000). Blessing in disguise: Another side of the near-death experience. St. Paul, MN: Llewellyn Publications.

Sabom, M. B. (1982). Recollections of death: A medical investigation. New York, NY: Harper and Row.

Sabom, M. B. (1998). Light and death: One doctor's fascinating account of near-death experiences. Grand Rapids, MI: Zondervan. 
Schwaninger, J., Eisenberg, P. R., Schechtman, K. B., and Weiss, A. N. (2002). A prospective analysis of near-death experiences in cardiac arrest patients. Journal of Near-Death Studies, 20, 215-232.

Spong, J. S. (1973). Honest prayer. New York, NY: Seabury Press.

Spong, J. S. (1980). The Easter moment. San Francisco, CA: Harper and Row.

Spong, J. S. (1994). Resurrection: Myth or reality? A bishop's search for the origins of Christianity. San Francisco, CA: HarperSanFrancisco.

Spong, J. S. (1996). Liberating the gospels. San Francisco, CA: HarperSanFrancisco.

Spong, J. S. (1998). Why Christianity must change or die: A Bishop speaks to believers in exile. San Francisco, CA: HarperSanFrancisco.

Spong, J. S. (2001). A new Christianity for a new world: Why traditional faith is dying and how a new faith is being born. San Francisco, CA: Harper SanFrancisco.

Vaitl, D., Birbaumer, N., Gruzelier, J., Jamieson, G. A., Kotchoubey, B., Kübler, A., Lehmann, D., Miltner, W. H. R., Ott, U., Pütz, P., Sammer, G., Strauch, I., Strehl, U., Wackermann, J., and Weiss, T. (2005). Psychobiology of altered states of consciousness. Psychological Bulletin, 131, 98-127.

van Lommel, P., van Wees, R., Meyers, V., and Elfferich, I. (2001). Near-death experience in survivors of cardiac arrest: A prospective study in the Netherlands. Lancet, 358, 2039-2045.

Wade, J. (1996). Changes of mind: A holonomic theory of the evolution of consciousness. Albany, NY: State University of New York Press.

Wilson, D. (1995, August). Personal testimony [Panel of near-death experiencers]. Presented at the North American Conference of the International Association of NearDeath Studies, West Hartford, CT. 